\title{
EFEK ANTIINFLAMASI EKSTRAK ETANOL KULIT KACANG TANAH (Arachis hypogaea L.) PADA TIKUS PUTIH JANTAN GALUR WISTAR YANG DIINDUKSI KARAGENIN
}

\section{ANTIINFLAMATION EFFECT OF ETHANOLIC EXTRACT PEANUT SHELL (Arachis hypogaea L.) ON MALE RAT INDUCED BY CARAGENIN}

\author{
Haryoto*, Kendri Sri Yuliati, Nurcahyanti Wahyuningtyas \\ Fakultas Farmasi, Universitas Muhammadiyah Surakarta \\ haryo62@gmail.com
}

\begin{abstract}
ABSTRAK
Kulit kacang tanah mengandung luteolin yang berpotensi sebagai antiinflamasi secara in vitro dan in vivo. Penelitian ini bertujuan untuk mengetahui efek antiinflamasi ekstrak etanol kulit kacang tanah (Arachis hypogaea L.) pada tikus jantan galur Wistar yang diinduksi karagenin Penelitian menggunakan rancangan acak lengkap pola searah. Dua puluh lima ekor tikus putih jantan galur Wistar dibagi menjadi 5 kelompok. Kontrol negatif menggunakan CMC-Na 0,5\% 2,5 $\mathrm{mL} / 200 \mathrm{gBB}$, kontrol positif menggunakan Na-diklofenak 6,75 mg/kgBB. Ekstrak etanol kulit kacang tanah yang diujikan yaitu dosis 50, 100 dan $200 \mathrm{mg} / \mathrm{kgBB}$. Larutan uji diberikan secara peroral dengan volume pemberian 2,5 mL/200 gBB 1 jam sebelum kaki hewan uji diradangkan dengan karagenin 1\% secara subplantar. Pengukuran volume kaki tikus dilakukan tiap 0,5 jam selama 6 jam. Data volume udem dihitung nilai AUC (Area Under the Curve) rata-rata volume udem terhadap waktu dan persen daya antiinflamasi. Data dianalisis dengan anava satu jalan dan dilanjutkan uji LSD (Least Significant Difference) dengan taraf kepercayaan 95\%. Hasil penelitian menunjukkan bahwa ekstrak etanol etanol kulit kacang tanah (Arachis hypogae L.) dengan dosis 50, 100 dan $200 \mathrm{mg} / \mathrm{kgBB}$ mempunyai persen daya antiinflamasi berturut-turut sebesar 16,33\%; 26,39\% dan 31,70\%, sedangkan Na-diklofenak $6,75 \mathrm{mg} / \mathrm{kgBB}$ sebesar $32,24 \%$.
\end{abstract}

Kata kunci: kulit kacang tanah (Arachis hypogaea L.), ekstrak etanol, antiinflamasi

ABSTRACT

The peanut shell contain luteolin, which has antiinflammation activity in vitro and in vivo. This research aims to proved the antiinflammation effects of ethanol extract from peanut shells (Arachis hypogae L.) in Wistar male rats induced by subplantar carrageenan $1 \%$. The research method used completely randomized design. Twenty five Wistar male rats divided into five groups. The negative control used CMC-Na 0.5\% 2,5 mL/200 gBW, the positive control used Na-diclofenak $6.75 \mathrm{mg} / \mathrm{kgBW}$. The ethanol extract peanut shells (Arachis hypogae L.) doses tested were 50, 100 and $200 \mathrm{mg} / \mathrm{kgBW}$. The test solution was given orally $2.5 \mathrm{~mL} / 200 \mathrm{gBW}$ one hour before the rat paw induced by subplantar carrageenan $1 \%$. The edema volume was measured every half hour for six hours. The edema volume obtained AUC values (the average of edema volume versus time) and calculated percent inhibition of inflammatory. The data were analyzed by one way Anova followed by LSD (Least Significant Difference) test with 95\% confidence level. The result showed the ethanol extract peanut shells (Arachis hypogae L.) at dose of 50, 100 and $200 \mathrm{mg} / \mathrm{kgBW}$ has percent inhibition of inflammatory in Wistar male rats in a raw at $16.33 \%, 26,39 \%$ and $31,70 \%$, while Na-diklofenak 6,75 mg/kgBW as 32,24\%.

Keywords: peanut shell (Arachis hypogae, L.), ethanol extract, antiinflammation

\section{PENDAHULUAN}

Salah satu penyakit yang banyak diderita oleh masyarakat adalah inflamasi atau radang. Inflamasi memiliki angka kejadian yang cukup tinggi. Inflamasi dapat disebabkan oleh trauma fisik, infeksi maupun reaksi antigen dari penyakit; seperti terpukul benda tumpul dan infeksi bakteri pada luka terbuka (timbulnya nanah pada luka) yang dapat menimbulkan nyeri dan dapat mengganggu aktivitas (Noer dan Wasradji, 1996).

Kulit kacang tanah yang selama ini kurang dimanfaatkan oleh masyarakat, ternyata mempunyai beberapa kandungan kimia yang bermaanfaat bagi kesehatan. Kandungan kimia dari kulit kacang tanah antara lain luteolin, eriodictyol, dan 5,7-dihydroxychromone (De Lucca et al., 1987). Luteolin banyak terdapat pada kulit kacang tanah yang telah masak, sedangkan eriodictyol lebih banyak terdapat pada kulit kacang tanah yang belum masak (Daigle et al., 1988). Luteolin merupakan flavonoid tanaman yang berpotensi sebagai antiinflamasi secara in vitro dan in vivo (Chen et al., 2007). Luteolin (flavon) mempunyai aktivitas antiinflamasi dengan memodulasi ekspresi gen 
proinflammatory seperti COX2, menginduksi nitric oxide synthase dan sitokin ( $\mathrm{Kim}$ et al., 2004). Luteolin secara oral dapat digunakan pada kondisi alergi, inflamasi kronik (pernapasan, gastrointestinal, tulang), arterosklerosis dan gangguan vaskuler lainnya. Luteolin pada penggunaan luar dapat digunakan untuk alergi kulit/inflamasi dan pencegahan kanker kulit (Anonim, 2007).

Kulit kacang tanah (Arachis hypogaea, L.) mengandung senyawa luteolin seperti terurai di atas maka dilakukan penelitian dengan tujuan untuk mengetahui apakah kulit kacang tanah (Arachis hypogaea, L.) mempunyai aktivitas antiinflamasi pada tikus putih jantan galur Wistar yang telah diinduksi karagenin. Hasil penelitian yang diperoleh dapat memberikan informasi tambahan mengenai manfaat penggunaan kulit kacang tanah sebagai salah satu obat alami yang berkhasiat sebagai antiinflamasi atau anti radang.

\section{METODE PENELITIAN}

\section{A. Alat Dan Bahan}

Alat yang digunakan yaitu: blender (Miyako), ayakan no. 8/16 mesh, neraca analitik, evaporator, dan alat-alat gelas (pyrex), pletismometer (kepekaan 0,05 mL), spuit injeksi $1 \mathrm{~mL}$ dan $3 \mathrm{~mL}$ (Terumo), jarum oral, pengukur waktu, timbangan tikus.

Bahan:

1. Kulit kacang tanah (Arachis hypogaea, L.) yang berasal dari Karangasem, Nguter, Sukoharjo.

2. Bahan kimia untuk uji daya antiinflamasi: Natrium diklofenak, Etanol $70 \%$ teknis, karagenin, Natrium klorida, dan CMC-Na 0,5\%.

3. Hewan uji yang digunakan dalam penelitian adalah tikus putih jantan galur Wistar berumur 2-3 bulan dengan berat badan 150-200 g yang berasal dari PHPM Kentungan Sleman Yogyakarta dengan surat keterangan pembelian hewan uji nomor 75/Ktg/SIm/Rt.04/2010.

\section{B. Jalannya Penelitian}

1. Determinasi Tanaman

Determinasi tanaman dilakukan di Laboratorium Taksonomi Tumbuhan Fakultas Biologi Universitas Gadjah Mada, Yogyakarta dengan surat keterangan nomor 0168/T.Tb./III/2010.

\section{Pembuatan Simplisia}

Kulit kacang tanah dibersihkan dan dijemur di bawah sinar matahari dengan ditutup kain hitam untuk menghindari rusaknya senyawa pada kulit kacang tanah yang sudah kering diserbuk menggunakan blender dan diayak dengan ayakan no. 8/16.

\section{Pembuatan Ekstrak Etanol Kulit Kacang Tanah}

Pembuatan ekstrak kulit kacang tanah dengan cara maserasi menggunakan etanol $70 \%$. Simplisia sejumlah $3,917 \mathrm{~kg}$ dituangi dengan $25 \mathrm{~L}$ cairan penyari dan ditutup. Rendaman simplisia kulit kacang tanah dibiarkan selama 5 hari terlindung dari cahaya sambil sering diaduk, diserkai, diperas, dicuci ampasnya dengan cairan penyari secukupnya hingga diperoleh $14,7 \mathrm{~L}$. Maserat dievaporasi dan dikeringkan dengan waterbath hingga terbentuk ekstrak kental yang liat, sulit dituang dan ditimbang berat ekstrak kentalnya.

\section{Pembuatan Suspensi Karagenin $1 \%$}

Karagenin ditimbang seksama 0,05 gram dilarutkan dalam $5 \mathrm{~mL}$ larutan garam fisiologis $(\mathrm{NaCl} 0,9 \%)$.

\section{Pembuatan Na-diklofenak Konsentrasi 54 $\mathrm{mg} / \mathbf{1 0 0} \mathrm{mL}$}

Suspensi Na-diklofenak dosis 6,75 $\mathrm{mg} / \mathrm{kgBB}$ dibuat dalam Konsentrasi $54 \mathrm{mg} / 100$ $\mathrm{mL}$ yang diberikan peroral pada tikus dengan volume 2,5 mL/200 gBB. Pembuatan suspensi Na-diklofenak $54 \mathrm{mg} / 100 \mathrm{~mL}$ dengan menimbang seksama $54 \mathrm{mg}$ Na-diklofenak ditambahkan $100 \mathrm{~mL}$ larutan CMC-Na 0,5\% dalam labu takar $100 \mathrm{~mL}$.

\section{Pembuatan Radang Pada Kaki Tikus}

Kaki tikus ditandai sampai batas mata kaki dengan spidol ujung runcing. Kemudian diinjeksi $0,1 \mathrm{~mL}$ larutan karagenin $1 \%$ subplantar (di bawah kulit telapak kaki tikus) setelah pemberian peroral Na-diklofenak atau ekstrak etanol kulit kacang tanah.

\section{Uji Pendahuluan \\ a. Orientasi Udem}

Orientasi dilakukan dengan mengukur salah satu kaki tikus menggunakan pletismometer sebagai volume awal (kontrol negatif). Kaki tikus tersebut diinjeksi dengan karagenin $1 \%$. Pengukuran dilakukan tiap 0,5 jam dari waktu 0 hingga volume kaki kembali normal. Pola udem yang diperoleh digunakan sebagai dasar pengukuran udem dalam pengujian.

\section{b. Orientasi Dosis Na-diklofenak}

Penetapan dosis Na-diklofenak dilakukan dengan menggunakan 9 ekor hewan uji dibagi menjadi 3 kelompok. Na-diklofenak yang digunakan adalah dosis $6,75 \mathrm{mg} / \mathrm{kgBB}$ dan $13,5 \mathrm{mg} / \mathrm{kgBB}$ yang diberikan secara peroral. Tiga kelompok perlakuan tersebut yaitu:

Kelompok $\mathrm{A}$ : kontrol negatif diberi CMC-Na $0,5 \% 2,5 \mathrm{~mL} / 200 \mathrm{gBB}$. 
Kelompok B : kontrol positif diberi Na-diklofenak dosis $6,75 \mathrm{mg} / \mathrm{kgBB}$.

Kelompok C : kontrol positif diberi $\mathrm{Na}$ diklofenak dosis $13,5 \mathrm{mg} / \mathrm{kgBB}$.

Pemberian dilakukan 1 jam sebelum kaki tikus diinduksi larutan secara subplantar dengan 0,1 $\mathrm{mL}$ larutan karagenin $1 \%$. Volume kaki tikus diukur menggunakan pletismometer sesaat setelah diinjeksi karagenin sebagai volume waktu ke 0 dan tiap 0,5 jam selama 6 jam.

\section{c. Penetapan Waktu Pemberian Na- diklofenak $6,75 \mathrm{mg} / \mathrm{kgBB}$}

Penetapan waktu pemberian $\mathrm{Na}$ diklofenak dilakukan dengan menggunakan 9 ekor hewan uji dibagi menjadi 3 kelompok. Nadiklofenak dosis $6,75 \mathrm{mg} / \mathrm{kgBB}$ diberikan peroral pada 1 jam; 0,5 jam dan sesaat sebelum diberikan injeksi subplantar karagenin $1 \%$. Volume kaki tikus diukur pada pletismometer sesaat setelah diinjeksi karagenin sebagai volume waktu ke 0 dan setiap 0,5 jam selama 6 jam.

\section{d. Orientasi Dosis Ekstrak Etanol Kulit Kacang Tanah}

Orientasi dosis yang diberikan 12,5, 50 dan $100 \mathrm{mg} / \mathrm{kgBB}$ ekstrak etanol kulit kacang tanah (Arachis hypogaea L.) masing-masing menggunakan 3 ekor hewan uji. Hewan uji diberikan ekstrak etanol kulit kacang tanah dengan volume pemberian $2,5 \mathrm{~mL} / 200 \mathrm{gBB}$ diberikan peroral 1 jam sebelum diinjeksi subplantar karagenin 1\% kemudian diukur volume kaki tikus yang sudah ditandai dengan pletismometer setiap 0,5 jam selama 6 jam.

\section{e. Penetapan Waktu Pemberian Ekstrak Etanol Kulit Kacang Tanah}

Penetapan waktu pemberian ekstrak etanol kulit kacang tanah dilakukan dengan menggunakan 9 ekor hewan uji dibagi menjadi 3 kelompok, masing-masing 3 hewan uji. Hewan uji diberikan ekstrak etanol kulit kacang tanah dosis $200 \mathrm{mg} / \mathrm{kgBB}$ dengan volume pemberian 2,5 mL/200 gBB diberikan peroral pada 1 jam; 0,5 jam dan sesaat sebelum induksi karagenin $1 \%$, kemudian diukur volume kaki tikus yang sudah ditandai dengan pletismometer setiap 0,5 jam selama 6 jam.

8. Uji Efek Antiinflamasi Ekstrak Etanol Kulit Kacang Tanah (Arachis hypogaea, L.) pada Tikus Putih Jantan Galur Wistar

Dua puluh lima ekor tikus putih jantan galur Wistar dipuasakan selama 18-24 jam dibagi menjadi 5 kelompok yang dipilih secara acak. Kaki tikus sebelah kiri ditandai sebatas mata kaki dengan spidol ujung runcing dan diukur volume kakinya dengan pletismometer sebagai volume kaki awal (Vo). Tikus diberi perlakuan peroral dengan CMC-Na 0,5\% (kontrol negatif) $2,5 \mathrm{~mL} / 200 \mathrm{gBB}, \mathrm{Na}$-diklofenak $6,75 \mathrm{mg} / \mathrm{kgBB}$ (kontrol positif) $2,5 \mathrm{~mL} / 200 \mathrm{gBB}$ dan ekstrak etanol kulit kacang tanah (kelompok uji) dengan dosis $50 \mathrm{mg} / \mathrm{kgBB}, 100$ $\mathrm{mg} / \mathrm{kgBB}$ dan $200 \mathrm{mg} / \mathrm{kgBB}$ dengan volume pemberian $2,5 \mathrm{~mL} / 200 \mathrm{gBB}$ tikus. Perlakuan ini dilakuan 1 jam sebelum induksi karagenin $1 \%$. Induksi $0,1 \mathrm{~mL}$ karagenin $1 \%$ dilakukan pada kaki tikus secara subplantar (di bawah kulit telapak kaki tikus) dan diukur volume kaki tikus yang sudah ditandai dengan pletismometer setiap 0,5 jam selama 6 jam (Vt).

\section{Analisis Data}

Data yang diperoleh berupa volume udem kaki tikus pada waktu tertentu kemudian dihitung volume udemnya. Volume udem merupakan selisih volume kaki tikus sebelum dan sesudah diradangkan dengan injeksi subplantar karagenin $1 \%$ dengan rumus:

$$
\mathrm{Vu}=\mathrm{Vt}-\mathrm{Vo}_{\mathrm{o}}
$$

Keterangan:

Vu: Volume udem kaki tikus tiap waktu $t$

Vt:Volume kaki tikus setelah diradangkan dengan karagenin $1 \%$ pada waktu $t$

Vo: Volume awal kaki tikus sebelum diradangkan dengan karagenin $1 \%$

Data volume udem kaki tersebut dapat dicari nilai AUC (Area Under Curve) yaitu luas daerah rata-rata di bawah kurva yang merupakan hubungan volume udem rata-rata tiap satuan waktu dengan rumus:

$$
\mathrm{AUC}_{\mathrm{t}_{\mathrm{n}-1}}^{\mathrm{t}_{\mathrm{n}}}=\frac{\mathrm{Vu}_{\mathrm{n}-1}+\mathrm{Vu}_{\mathrm{n}}}{2}\left(\mathrm{t}_{\mathrm{n}}-\mathrm{t}_{\mathrm{n}-1}\right)
$$

Keterangan:

$\mathrm{Vu}_{\mathrm{n}-1}$ : Volume udem rata-rata pada $t_{n-1}$

$V u_{n}$ : Volume udem rata-rata pada $t_{n}$

$$
\text { Persen daya antiinflamasi }
$$

(penghambatan volume udem) dihitung berdasarkan persen penurunan udem menggunakan rumus:

$$
\% \mathrm{DAI}=\frac{\mathrm{AUC}_{\mathrm{k}}-\mathrm{AUC}_{\mathrm{p}}}{\mathrm{AUC}_{\mathrm{k}}} \times 100 \%
$$

Keterangan:

$\mathrm{AUC}_{\mathrm{k}}$ : AUC kurva volume udem rata-rata terhadap waktu untuk kontrol negatif

$A \cup C_{p}$ : AUC kurva volume udem terhadap waktu untuk kelompok pelakuan pada tiap individu.

Data AUC (Area Under Curve) antara volume udem dengan waktu kemudian dilakukan uji uji analisis varian satu jalan (Oneway Anova) dengan taraf kepercayaan 95\%. dan analisis Post Hoc Test dengan uji LSD (Least Significant Difference) dengan taraf kepercayaan $95 \%$. 
HASIL DAN PEMBAHASAN

\section{A. Determinasi Tanaman Dan Hasil Ekstraksi Ekstrak Etanol Kulit Kacang Tanah}

Determinasi tanaman dilakukan dengan mengamati morfologi tanaman dan dicocokkan dengan kunci determinasi pada buku Flora of Java (Spermatophytes only) (Becker et.al., 1968).

Kacang tanah yang dipanen sebanyak 30 $\mathrm{kg}$. Setelah melalui proses pengeringan dan penyerbukan diperoleh $3,917 \mathrm{~kg}$ serbuk kulit kacang tanah kering. Setelah dievaporasi dan dikeringkan menggunakan waterbath diperoleh berat total ekstrak etanol kulit kacang tanah kental sebanyak 44,80 gram.

\section{B. Uji Pendahuluan}

Uji pendahuluan yang pertama adalah orientasi pola udem. Orientasi ini dilakukan untuk mengetahui pola udem yang terjadi pada kaki tikus setelah diinduksi karagenin $1 \%$. Pola udem dapat digunakan untuk melihat kemampuan karagenin dalam menginduksi terjadinya udem pada kaki tikus (Gambar 1).

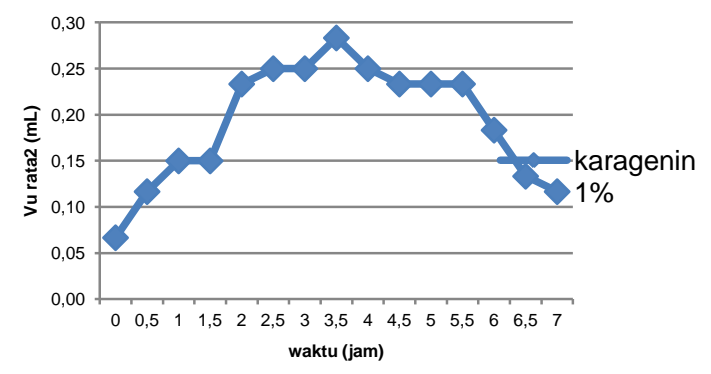

Gambar 1 - Grafik Volume Udem Orientasi Pola Udem.

Dosis Na-diklofenak yang digunakan untuk orientasi adalah dosis 6,75 dan 13,5 $\mathrm{mg} / \mathrm{kgBB}$. Hasil menunjukkan tidak ada perbedaan efek antiinflamasi antara kedua dosis Na-diklofenak. Dosis yang dipilih sebagai kontrol positif adalah $6,75 \mathrm{mg} / \mathrm{kgBB}$ dengan pertimbangan klinis untuk meminimalkan efek samping yang mungkin muncul dari penggunaan Na-diklofenak (tabel 1).

Tabel 1-Data AUC dan \% DAI Kontrol Negatif CMC-Na 0,5\% 2,5 mL/200 gBB, Na-diklofenak 6,75 dan 13,5 mg/kgBB 1 Jam Sebelum Karagenin 1\%

\begin{tabular}{|c|c|c|}
\hline Perlakuan & $\begin{array}{l}\text { Nilai AUC } \\
\text { (mL. jam) } \\
\text { X } \pm \text { SEM }\end{array}$ & $\begin{array}{c}\text { Persen } \\
\text { Daya } \\
\text { Antiinflamasi } \\
\text { X } \pm \text { SEM }\end{array}$ \\
\hline $\begin{array}{c}\text { Kontrol negatif CMC-Na } \\
0,5 \% 2,5 \mathrm{~mL} / 200 \mathrm{gBB}\end{array}$ & $1,54 \pm 0,15$ & 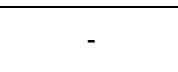 \\
\hline $\begin{array}{c}\text { Na-diklofenak } 6,75 \\
\text { mg/kgBB }\end{array}$ & $0,71 \pm 0,21^{*}$ & $53,68 \pm 13,48$ \\
\hline $\begin{array}{c}\text { Na-diklofenak 13,5 } \\
\text { mg/kgBB }\end{array}$ & $1,09 \pm 0,07$ & $29,22 \pm 4,79$ \\
\hline $\begin{array}{l}\text { Keterangan: } \\
\text { SEM } \quad \text { : Rata-rata AUC } \\
\text { Standard Error }\end{array}$ & & \\
\hline
\end{tabular}

Uji pendahuluan yang ketiga adalah orientasi waktu pemberian Na-diklofenak 6,75 $\mathrm{mg} / \mathrm{kgBB}$. Waktu pemberian yang akan diorientasi adalah waktu pemberian 1 jam; 0,5 jam dan sesaat sebelum induksi karagenin $1 \%$. Waktu pemberian 1 jam mempunyai efek antiinflamasi yang lebih besar dibandingkan waktu pemberian lainnya $(p<0,05)$, sehingga Na-diklofenak $6,75 \mathrm{mg} / \mathrm{kgBB}$ diberikan 1 jam sebelum induksi karagenin 1\% (tabel 2 ).

Tabel 2-Data AUC dan \% DAl Waktu Pemberian Nadiklofenak $6,75 \mathrm{mg} / \mathrm{kgBB} 1 \mathrm{Jam}, 0,5 \mathrm{Jam}$ dan Sesaat Sebelum Induksi Karagenin 1\%

\begin{tabular}{|c|c|c|}
\hline Perlakuan & $\begin{array}{l}\text { Nilai AUC } \\
\text { (mL. jam) } \\
\text { X } \pm \text { SEM }\end{array}$ & 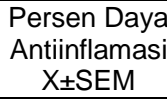 \\
\hline $\begin{array}{l}\text { Kontrol negatif CMC- } \\
\mathrm{Na} 0,5 \% 2,5 \mathrm{~mL} / 200 \\
\text { gBB }\end{array}$ & $1,54 \pm 0,15$ & 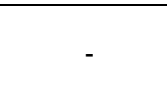 \\
\hline $\begin{array}{l}\text { Na-diklofenak } 1 \text { jam } \\
\text { sebelum induksi } \\
\text { karagenin } 1 \%\end{array}$ & $0,71 \pm 0,21^{*}$ & $53,68 \pm 1,48$ \\
\hline $\begin{array}{l}\text { Na-diklofenak 0,5 jam } \\
\text { sebelum induksi } \\
\text { karagenin } 1 \%\end{array}$ & $1,61 \pm 0,32$ & $-4,33 \pm 20,62$ \\
\hline $\begin{array}{l}\text { Na-diklofenak sesaat } \\
\text { sebelum induksi } \\
\text { karagenin } 1 \%\end{array}$ & $1,19 \pm 0,13$ & $22,73 \pm 8,48$ \\
\hline \multicolumn{2}{|l|}{ Keterangan: } & \\
\hline
\end{tabular}

Uji pendahuluan keempat adalah orientasi dosis ekstrak etanol kulit kacang tanah. Pemilihan dosis yang digunakan pada orientasi dosis ekstrak yaitu 12,5, 50 dan 200 $\mathrm{mg} / \mathrm{kgBB}$. Dosis $200 \mathrm{mg} / \mathrm{kgBB}$ menunjukkan tidak ada perbedaan efek antiinflamasi dengan kontrol positif Na-diklofenak $6,75 \mathrm{mg} / \mathrm{kgBB}$ (tabel 3).

Tabel 3- Data AUC dan \% DAI Orientasi Dosis Ekstrak Etanol Kulit Kacang Tanah Dosis 12,5; 50 dan 200 $\mathrm{mg} / \mathrm{kgBB} 1 \mathrm{Jam}$ Sebelum Induksi Karagenin 1\%

\begin{tabular}{|c|c|c|}
\hline Perlakuan & $\begin{array}{c}\text { Nilai AUC (mL. } \\
\text { jam) } \\
X \pm S E M\end{array}$ & 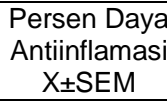 \\
\hline $\begin{array}{l}\text { kontrol negatif } \\
\mathrm{CMC}-\mathrm{Na} 0,5 \% \\
2,5 \mathrm{~mL} / 200 \mathrm{gBB}\end{array}$ & $1,54 \pm 0,15$ & - \\
\hline $\begin{array}{l}\text { Na-diklofenak } \\
6,75 \mathrm{mg} / \mathrm{kgBB} \\
\text { ekstrak etanol }\end{array}$ & $0,71 \pm 0,21^{*}$ & $53,68 \pm 13,48$ \\
\hline $\begin{array}{l}\text { kulit kacang } \\
\text { tanah } 12,5 \\
\mathrm{mg} / \mathrm{kgBB} \\
\text { ekstrak etanol }\end{array}$ & $1,21 \pm 0,09$ & $21,43 \pm 6,03$ \\
\hline $\begin{array}{l}\text { kulit kacang } \\
\text { tanah } 50 \\
\mathrm{mg} / \mathrm{kgBB} \\
\text { ekstrak etanol }\end{array}$ & $1,29 \pm 0,24$ & $16,66 \pm 15,61$ \\
\hline $\begin{array}{l}\text { kulit kacang } \\
\text { tanah } 200 \\
\mathrm{mg} / \mathrm{kgBB}\end{array}$ & $0,73 \pm 0,27^{*}$ & $52,82 \pm 17,32$ \\
\hline $\begin{array}{l}\text { Keterangan: } \\
\text { X }\end{array}$ & $\begin{array}{l}\text { C } \\
\text { ror of Mean }\end{array}$ & \\
\hline
\end{tabular}


Hasil uji menunjukkan hanya kontrol positif dan ekstrak dosis $200 \mathrm{mg} / \mathrm{kgBB}$ yang mempunyai perbedaan efek dengan kontrol negatif CMC-Na 0,5\%. Ekstrak etanol kulit kacang tanah dosis $200 \mathrm{mg} / \mathrm{kgBB}$ menunjukkan penghambatan udem yang sama dengan Na-diklofenak $6,75 \mathrm{mg} / \mathrm{kgBB}(\mathrm{p}>0,05)$.

Uji pendahuluan kelima adalah orientasi waktu pemberian ekstrak etanol kulit kacang tanah. Orientasi dilakukan dengan menggunakan dosis $200 \mathrm{mg} / \mathrm{kgBB}$ dengan waktu pemberian 1 jam; 0,5 jam dan sesaat sebelum induksi dengan karagenin $1 \%$. Hasil menunjukkan bahwa waktu pemberian ekstrak etanol kulit kacang tanah $200 \mathrm{mg} / \mathrm{kgBB} 1$ jam sebelum injeksi karagenin $1 \%$ tidak mempunyai perbedaan dalam penghambatan udem dengan Na-diklofenak 6,75 mg/kgBB (table 4).

Tabel 4-Data AUC dan \% DAI Waktu Pemberian Ekstrak Etanol Kulit Kacang Tanah Dosis $200 \mathrm{mg} / \mathrm{kgBB} 1 \mathrm{Jam}, 0,5$ Jam dan Sesaat Sebelum Induksi Karagenin 1\%

\begin{tabular}{|c|c|c|}
\hline Perlakuan & $\begin{array}{l}\text { Nilai AUC } \\
\text { (mL. jam) } \\
\text { X } \pm \text { SEM }\end{array}$ & $\begin{array}{c}\text { Persen Daya } \\
\text { Antiinflamasi } \\
\text { X } \pm \text { SEM }\end{array}$ \\
\hline $\begin{array}{l}\text { kontrol negatif CMC- } \\
\mathrm{Na} \mathrm{0,5 \%} \mathrm{2,5} \mathrm{mL/200} \\
\text { gBB }\end{array}$ & $1,54 \pm 0,15$ & 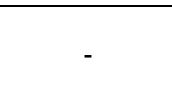 \\
\hline $\begin{array}{l}\text { Na-diklofenak 6,75 } \\
\text { mg/kgBB } \\
\text { ekstrak etanol kulit }\end{array}$ & $0,71 \pm 0,21^{*}$ & $53,68 \pm 13,48$ \\
\hline $\begin{array}{l}\text { kacang tanah } 1 \text { jam } \\
\text { sebelum } \\
\text { ekstrak etanol kulit }\end{array}$ & $0,73 \pm 0,27^{*}$ & $52,82 \pm 17,32$ \\
\hline $\begin{array}{l}\text { kacang tanah } 0,5 \\
\text { jam sebelum } \\
\text { ekstrak etanol kulit }\end{array}$ & $1,38 \pm 0,25$ & $10,39 \pm 16,13$ \\
\hline $\begin{array}{l}\text { kacang tanah sesaat } \\
\text { sebelum }\end{array}$ & $1,15 \pm 0,33$ & $25,33 \pm 21,14$ \\
\hline $\begin{array}{l}\text { Keterangan: } \\
X \quad \text { : rata-rata AL } \\
\text { SEM } \quad \text { : Standard }\end{array}$ & & \\
\hline
\end{tabular}

Berdasarkan hasil uji pendahuluan yang telah dilakukan maka kontrol negatif yang digunakan pada penelitian ini adalah CMC-Na $0,5 \% 2,5 \mathrm{~mL} / 200 \mathrm{gBB}$, kontrol positif $\mathrm{Na}$ diklofenak $6,75 \mathrm{mg} / \mathrm{kgBB} 1$ jam sebelum induksi karagenin $1 \%$ dan ekstrak etanol kulit kacang tanah $200 \mathrm{mg} / \mathrm{kgBB} 1$ jam sebelum induksi karagenin $1 \%$ sebagai dosis uji tertinggi yang digunakan dalam penelitian.

\section{UJI EFEK ANTIINFLAMASI}

Penelitian efek antiinflamasi dilakukan pada tikus putih jantan galur Wistar yang mendapat perlakuan peroral ekstrak etanol kulit kacang tanah dengan dosis 50, 100 dan 200 $\mathrm{mg} / \mathrm{kgBB}$. Kontrol negatif CMC-Na 0,5\% dengan volume pemberian $2,5 \mathrm{~mL} / 200 \mathrm{gBB}$ dan kontrol positif Na-diklofenak $6,75 \mathrm{mg} / \mathrm{kgBB}$ waktu pemberian 1 jam sebelum diinduksi karagenin $1 \%$.
Tabel 5- Data AUC dan \% DAI Uji Efek Antiinflamasi Ekstrak Etanol Kulit Kacang Tanah Dosis 50, 100 dan 200 $\mathrm{mg} / \mathrm{kgBB}$

\begin{tabular}{|c|c|c|}
\hline Perlakuan & $\begin{array}{c}\text { Nilai AUC } \\
\text { (mL. jam) } \\
\text { X } \pm \text { SEM }\end{array}$ & 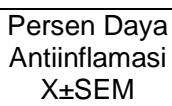 \\
\hline \multicolumn{3}{|l|}{ kontrol negatif CMC- } \\
\hline $\begin{array}{l}\mathrm{Na} 0,5 \% 2,5 \mathrm{~mL} / 200 \\
\mathrm{gBB}\end{array}$ & $1,47 \pm 0,10$ & - \\
\hline $\begin{array}{l}\text { Na-diklofenak 6,75 } \\
\mathrm{mg} / \mathrm{kgBB}\end{array}$ & $0,99 \pm 0,04$ & $32,24 \pm 2,38$ \\
\hline \multicolumn{3}{|l|}{ ekstrak etanol kulit } \\
\hline $\begin{array}{l}\text { kacang tanah } 50 \\
\mathrm{mg} / \mathrm{kgBB}\end{array}$ & $1,23 \pm 0,04$ & $16,33 \pm 2,71$ \\
\hline \multicolumn{3}{|l|}{$\begin{array}{l}\mathrm{mg} / \mathrm{kgBB} \\
\text { ekstrak etanol kulit }\end{array}$} \\
\hline $\begin{array}{l}\text { kacang tanah } 100 \\
\text { mg/kgBB } \\
\text { ekstrak etanol kulit }\end{array}$ & $1,08 \pm 0,05$ & $26,39 \pm 3,13$ \\
\hline $\begin{array}{l}\text { kacang tanah } 200 \\
\mathrm{mg} / \mathrm{kgBB}\end{array}$ & $1,00 \pm 0,04$ & $31,70 \pm 2,84$ \\
\hline \multicolumn{3}{|c|}{ Keterangan: } \\
\hline \multicolumn{3}{|c|}{ X $\quad$ : rata-rata AUC } \\
\hline \multicolumn{3}{|c|}{ SEM : Standard Error of Mean } \\
\hline
\end{tabular}

Daya antiinflamasi ekstrak etanol kulit kacang tanah paling besar ditunjukkan oleh pemberian dosis $200 \mathrm{mg} / \mathrm{kgBB}$ (tabel 5). Hasil uji statistik dapat diketahui bahwa kontrol positif Na-diklofenak $6,75 \mathrm{mg} / \mathrm{kgBB} 1$ jam sebelum diinduksi karagenin $1 \%$ tidak berbeda bermakna dengan ekstrak etanol kulit kacang tanah dosis 100 dan $200 \mathrm{mg} / \mathrm{kgBB} 1$ jam sebelum diinduksi karagenin $1 \%$. Hal ini berarti kedua dosis ekstrak etanol kulit kacang tanah tersebut memiliki kemampuan menghambat inflamasi yang sebanding dengan $\mathrm{Na}$ diklofenak $6,75 \mathrm{mg} / \mathrm{kgBB}$.

Penelitian menggunakan fraksi tidak larut air ekstrak etanol kulit kacang tanah dosis 50 $\mathrm{mg} / \mathrm{kgBB}$ diperoleh persen daya antiinflamasi sebesar $31,97 \%$. Persen daya antiinflamasi fraksi tidak larut air ekstrak etanol kulit kacang tanah dosis $50 \mathrm{mg} / \mathrm{kgBB}$ sebesar $31,97 \%$, sedangkan persen daya antiinflamasi ekstrak etanol kulit kacang tanah dosis $50 \mathrm{mg} / \mathrm{kgBB}$ sebesar $16,33 \%$. Hasil tersebut menunjukkan persen daya antiinflamasi pada fraksi tidak larut air ekstrak etanol kulit kacang tanah dosis 50 $\mathrm{mg} / \mathrm{kgBB}$ lebih besar dibanding persen daya antiinflamasi ekstrak etanol kulit kacang tanah, yang berarti potensi antiinflamasi dari ekstrak etanol kulit kacang tanah lebih besar pada fraksi yang tidak larut air.

Luteolin yang dominan pada kulit kacang tanah yang masak mempunyai efek antiinflamasi secara in vitro dan in vivo. Luteolin kurang larut dalam air dan lebih larut dalam alkali sehingga dimungkinkan kandungan luteolin dalam kulit kacang tanah lebih besar pada bagian yang tidak larut air.

\section{KESIMPULAN}

Hasil penelitian dapat diketahui bahwa ekstrak etanol kulit kacang tanah dengan dosis 
50, 100 dan $200 \mathrm{mg} / \mathrm{kgBB}$ mempunyai potensi sebagai antiinflamasi dengan persen daya antiinflamasi berturut-turut sebesar 16,33\%; $26,39 \%$ dan $31,70 \%$. Efek antiinflamasi dari ekstrak etanol kulit kacang tanah dosis 100 dan $200 \mathrm{mg} / \mathrm{kgBB}$ sebanding dengan Na-diklofenak dosis $6,75 \mathrm{mg} / \mathrm{kgBB}$.

\section{SARAN}

Perlu dilakukan penelitian lebih lanjut tentang efek antiinflamasi dari kulit kacang tanah (Arachys hypogaea L.). dengan fraksinasi bertingkat ke arah non polar dan isolasi senyawa yang terkandung dalam kulit kacang tanah (Arachys hypogaea L.) yang paling berperan memiliki aktivitas antiinflamasi.

\section{UCAPAN TERIMA KASIH}

Ucapan terima kasih disampaikan kepada Staff Laboratorium Taksonomi Tumbuhan Fakultas Biologi Universitas Gadjah Mada yang telah mengidentifikasi tumbuhan.

\section{DAFTAR PUSTAKA}

Anonim, 2007, Luteolin From Natural Source, Skyherb Technologies, (online) (http://www.skyherb.cn/showproduct.asp?productID=9) diakses tanggal 3 Juli 2010.

Becker, A.C., Utrecht, Sc.D., and Van den Brink, B.C.R., 1968, Flora of Java (Spermatophytes only), Volume 2, World of Bronirgen, Netherland.

Chen, CY., Peng, WH., Tsai, KD., and Hsu, SL., 2007, Luteolin Suppresses Inflammatoryassociated Gene Expression by Blocking NF- ${ }_{k} \mathrm{~B}$ and AP-1 Activation Pathway in Mouse Alveolar Macrophages, INIST-CNRS, volume 81, 1602-1614, (online) (http://cat.inist.fr/?aModele=afficheN\&cpsidt=19561932) diakses tanggal 3 Juli 2010.

Daigle, D. J., Conkerton, E. J., and Mixon, A. C., 1988, Peanut Hull Flavonoids: Their Relationship with Peanut Maturity, Journal of Agricultur and Food Chemistry, 36, 1179-1181, (online) (http://pubs.acs.org/doi/abs/10.1021/jf00084a013) diakses tanggal 3 Juli 2010.

De Lucca, A. J. II., Palmgren, M. S., and Daigle, D. J., 1987, Depression of Aflatoxin Production by Flavonoid-Type Compounds from Peanut Shells, Phytopathology 77: 1560-1563, (online) (http://www.apsnet.org/phyto/PDFS/1987/Phyto77n11 1560.pdf) diakses tanggal 3 juli 2010.

Kim, H. P., Son, K. H., Chang, H. W., and Kang, S. S., 2004, Anti-inflammatory Plant Flavonoids and Cellular Action Mechanisms, Journal Pharmacol Science, 96 (3):229-45, (online) (http://www.ncbi.nlm.nih.gov/pubmed/15539763) diakses tanggal 3 Juli 2010.

Noer, S., dan Wasradji, S., 1996, Buku Ajar Ilmu Penyakit Dalam, Jilid I, Balai Penerbitan Fakultas Kedokteran Universitas Indonesia : Jakarta. 